\title{
A note from Francisco H. G. Ferreira, outgoing editor-in-chief
}

\author{
Francisco Ferreira
}

Published online: 8 March 2014

(C) Springer Science+Business Media New York 2014

It has now been just over two years since I took over as editor in chief of the Journal of Economic Inequality. During this period, we have continued to build on the solid foundations laid by Jacques Silber and Jean-Yves Duclos, our previous editors. The Journal's impact factor has continued to grow, and is now higher than those of a number of older, more established journals in the field. Submissions have risen to over 180 in 2013-about one every other day. As a result, despite a growing page budget, the journal's acceptance rate has had to continue to decline.

Most importantly, I feel that we have continued to publish a number of very interesting papers, some of which will make a lasting contribution to how the profession understands inequality. The Forum, Book Review and Rediscovered Classics sections have continued to flourish, under the superb stewardship of Nora Lustig (Tulane University), Xavi Ramos (Universitat Autonoma de Barcelona) and Peter Lambert (University of Oregon), respectively. Most recently, following our editorial board meeting in Bari (Italy), we have also renewed the Editorial Board, and expanded our cadre of Associate Editors, bringing in Markus Jantti, of Stockholm University.

Markus joins an excellent group of Associate Editors, comprising Andrea Brandolini (Bank of Italy), Valentino Dardanoni (Universitá di Palermo), Cacilia García-Peñalosa (Aix-Marseille University) and Buhong Zheng (University of Colorado, Denver). Over the last two years, these four public-spirited scholars have contributed to the Journal very generously with their time and expertise, and I have felt truly privileged to work alongside them.

For various professional regions, I have resigned as Editor in Chief on January 31, 2014. I am delighted to report that Professor Stephen Jenkins, of the London School of Economics, has kindly agreed to replace me, and took over the helm on February 1st. Prof. Jenkins needs no introduction to anyone working on issues of economic inequality. He was appointed to the position by our publishers, Springer, following detailed consultations with the Society for the Study of Economic Inequality (ECINEQ). The Society, the publishers and I are truly

F. Ferreira $(\bowtie)$

World Bank, Washington, DC, USA

e-mail: fferreira@worldbank.org 
delighted that someone of Stephen's academic caliber has agreed to lead the Journal, and certain that he will take it to new heights.

I have learned a great deal during my short tenure as editor in chief of the Journal of Economic Inequality. I am thankful for the support I have received from ECINEQ and from the publishing team at Springer. I am especially grateful to my aforementioned fellow editors for all their hard work and valuable advice. Finally, I would particularly like to thank all of the Journal's authors, readers and referees for their continued interest in and contributions to the Journal. As with any scholarly publication, the journal is made by you and for you. I look forward to continue to learn from you in the future. 